\title{
Assessment of sFRP4 as a bio-marker for predicting aggressiveness and recurrence of growth hormone-secreting pituitary adenomas
}

\author{
YOUTU WU ${ }^{1}$, CHUNHUI LIU ${ }^{1}$, SHENGYUAN YU ${ }^{1}$, HUA GAO $^{1}$, \\ ZHENYE LI ${ }^{2}$, CHUZHONG LI $^{1}$ and YAZHUO ZHANG ${ }^{1,2}$ \\ ${ }^{1}$ Beijing Neurosurgical Institute, ${ }^{2}$ Neurosurgical Department, Beijing Tiantan Hospital, \\ Capital Medical University, Dongcheng, Beijing 100050, P.R. China \\ Received November 28, 2015; Accepted January 6, 2016
}

DOI: $10.3892 /$ or.2016.4650

\begin{abstract}
The association of sFRP4 expression with aggressiveness and recurrence of growth hormone (GH)-secreting pituitary adenomas was investigated. Ten normal pituitary and $52 \mathrm{GH}$-secreting pituitary adenoma specimens were classified into three groups: normal pituitary (control) group, non-aggressive group, and aggressive group, according to preoperative evaluation by magnetic resonance imaging (MRI)/computed tomography (CT). Expression of sFRP4 was determined by quantitative real-time polymerase chain reaction (qRT-PCR), western blot analysis, and tissue microarrays, to assess the association between sFRP4 and aggressiveness. Follow-up information of all 52 patients was collected to evaluate the impact of sFRP4 expression on the recurrence/progression of GH-secreting pituitary adenomas. qRT-PCR results showed a lower level of sFRP4 mRNA in the aggressive group, as compared to that in the non-aggressive group $(\mathrm{P}=0.001)$. A similar trend was observed on western blot analysis for sFRP4 protein expression $(\mathrm{P}=0.004)$. On analysis by tissue microarrays, weak sFRP4 expression was detected in the aggressive group $(10 / 15,66.7 \%)$. Univariate analysis showed a significant relationship between low sFRP4 expression and aggressiveness $(\mathrm{P}=0.024)$. On multivariate analysis weak sFRP4 expression was found to be an independent factor of recurrence/progression (odds ratio: $0.063, \mathrm{P}=0.026$ ). Methylation of the sFRP4
\end{abstract}

Correspondence to: Professor Yazhuo Zhang, Beijing Neurosurgical Institute, Capital Medical University, 6 Tiantan Xili, Dongcheng, Beijing 100050, P.R. China

E-mail: zyz2004520@yeah.net

Abbreviations: sFRPs, secreted frizzled-related proteins; $\mathrm{GH}$, growth hormone; CT, computed tomography; MRI, magnetic resonance imaging; NFPs, non-functioning pituitary adenomas; PCR, polymerase chain reaction; TMA, tissue microarray; IHC, immunohistochemistry; GAPDH, glyceraldehyde-3-phosphate dehydrogenase

Key words: sFRP4 expression, GH-secreting pituitary adenoma, aggressiveness, recurrence promoter was increased in low sFRP4 staining group compared to that in the high sFRP4 staining group $(\mathrm{P}<0.001)$. In this study, weak sFRP4 expression appeared to predict aggressive behavior, and was associated with recurrence/progression of GH-secreting pituitary adenomas. Methylation of the sFRP4 promoter may account for the low sFRP4 expression.

\section{Introduction}

Pituitary adenomas are relatively common neoplasms that account for $10-15 \%$ of all intracranial tumors. More than two-thirds of pituitary adenomas are characterized by excessive hormonal secretion, which manifests in the form of distinctive clinical syndromes $(1,2)$. Based on the clinical presentation, pituitary adenomas are classified as growth hormone- (GH), adrenocorticotropic hormone- (ACTH), prolactin- (PRL), and thyroid-stimulating hormone (TSH)-secreting pituitary adenomas, or clinically non-functional adenomas. The most common hormone-secreting adenomas are prolactinomas, followed by growth hormone $(\mathrm{GH})$ secreting and mixed $\mathrm{GH}$ and prolactin-producing adenomas (3).

Surgical resection is the primary therapeutic modality, although there are medical treatments available for $\mathrm{GH}$-secreting tumors (4). Indeed, in patients with intrasellar microadenomas, microsurgical removal of the tumor alone is sufficient for biochemical control as the procedure is associated with normalization of IGF-I in 75-95\% of patients. However, in macroadenomas or aggressive adenomas, surgery alone is not expected to achieve disease control or hormonal remission in most cases $(5,6)$. Surgical treatment of aggressive GH-secreting pituitary adenomas carries a high risk of recurrence/progression. These patients almost always need further therapy to achieve biochemical control of the disease. Currently, there is neither an effective methodology to distinguish non-aggressive $\mathrm{GH}$-secreting pituitary adenomas from aggressive adenomas, nor is there an efficient way to predict the recurrence/progression after surgery. Hence, research on bio-markers associated with aggressive pituitary adenomas and prognosis is a key imperative.

The Wnt signaling pathway is involved in several developmental processes, including, tissue differentiation, proliferation 
and apoptosis $(7,8)$. Aberrant regulation of the Wnt signaling pathway is thought to play a role in tumorigenesis (9), especially in pituitary adenomas $(10,11)$. The secreted frizzled related protein (sFRP) family, coded by a class of pro-apoptotic genes, is thought to play an important role in tumorigenesis by inhibiting Wnt signaling pathway (12). Upregulation of sFRPs expression, and in particular that of sFRP4, has been shown to correlate with apoptosis in various tissues (13-17). Further, the restoration or upregulation of sFRPs expression in cancer cells has been shown to attenuate grades and invasive growth characteristics of tumors such as, prostate, ovarian, and cervical cancer, which suggests that activities of sFRPs are fundamental for tissue homeostasis (18-23).

Elston et al (24) reported significant downregulation of sFRP4 in pituitary adenomas. Our previous study on gene microarrays also demonstrated significant downregulation of sFRP4 in aggressive NFPAs, as compared to that in nonaggressive NFPAs and normal pituitary tissues (25). Similar observations were forthcoming from yet another study conducted by our group, where we demonstrated a negative correlation of sFRP4 with aggressiveness of NFPAs (26).

Promoter hypermethylation often accounts for the loss of expression of tumor suppressor genes (27). Dense CpG islands flank the first exons of $s F R P 1, s F R P 2, s F R P 4$ and $s F R P 5$, but not $s F R P 3$. These sequences have been reported to be hypermethylated in several types of carcinoma, and particularly in colorectal, gastric, mammary, prostate, renal cell, and chronic lymphocytic leukemia (22,28-35).

In this study, we investigated the difference in sFRP4 expression between the aggressive GH pituitary adenoma and the non-aggressive GH pituitary adenoma through quantitative real-time polymerase chain reaction (qRT-PCR), western blot analysis, and tissue microarrays. The objective was to investigate the potential role of sFRP4 as a prognostic biomarker for GH-secreting pituitary adenomas, in terms of predicting aggressiveness and the risk of recurrence. Furthermore, methylation analysis of the sFRP4 promoter region was performed to figure out the underlying mechanism for abnormal expression of sFRP4.

\section{Materials and methods}

Ethical approval. All procedures performed in studies involving human participants were in accordance with the ethical standards of the Ethics Committee of Beijing Tiantan Hospital, Beijing, China, and with the 1964 Helsinki declaration and its later amendments or comparable ethical standards.

Sample collection. A total of 52 patients with GH-secreting pituitary adenoma (age range, 13-75 years) were enrolled at the Beijing Tiantan Hospital (2008-2012). None of the patients received somatostatin analog therapy in the preoperative period due to economic reasons.

The inclusion criteria were: i) availability of sufficient pituitary tissue specimen to allow for analysis by tissue microarrays; ii) no history of pre-operative radiation; iii) availability of clinical data, including endocrinological evaluation results and imaging results; iv) minimum follow-up duration of 3 years.
The diagnosis of biological behavior of the tumor was made on the basis of preoperative magnetic resonance imaging (MRI) and computed tomography (CT). Pituitary adenomas that were classified as grade III or IV according to Hardy or Knops classification were defined as aggressive.

Ten specimens of normal pituitary glands were obtained from a donation program. The donors included 6 men and 4 women aged 21-45 years (mean age, 35 years). All of the donors had died of non-neurological diseases. Written informed consent was obtained from all donors prior to their enrollment; the study protocol was approved by the Ethics Committee at the Beijing Tiantan Hospital, Beijing, China.

Specimens were categorized into three groups: the normal pituitary control group, non-aggressive group and aggressive group. Pituitary tumors were removed by trans-sphenoidal surgery and immediately 'flash-frozen' in liquid nitrogen until further analyses. Suitable parts of each sample were embedded in paraffin.

All patients were diagnosed based on clinical symptoms, preoperative sellar MRI and postoperative histopathological examination. Postoperative sella MRI scans were performed within $72 \mathrm{~h}$ after surgery, to evaluate the residual mass. Two neuroradiologists, and one neurosurgeon blinded to the patients' characteristics conducted the evaluation. The same were repeated at 6 -month intervals in the first 2 postoperative years. To investigate for tumor recurrence, serial sella MRI scans were performed at 1-year intervals. However, in the presence of clinical symptoms, sella MRI scan was performed immediately. Recurrence/progression was defined on the basis of 1 or more of the following parameters: i) presence of a new tumor in patients with a total resection, based on the first post-operative MRI scan; ii) evidence of new growth of an incompletely resected tumor on serial postoperative MRI scans versus the immediate postoperative MRI scan; iii) clinical deterioration or recurrence of symptoms after surgery, and associated with elevated serum hormone levels.

Preoperative serum GH levels were recorded to estimate the association of serum GH level with aggressiveness and recurrence/progression of tumors. The results were categorized as high level ( $\geq$ median level) and low level $(<$ median level).

Quantitative real-time polymerase chain reaction. Total RNA was isolated from frozen pituitary adenomas and normal pituitaries (100-150 mg) using TRIzol reagent (Invitrogen Life Technologies, 15596-026). The housekeeping gene coding for glyceraldehyde-3-phosphate dehydrogenase (GAPDH) was used as an internal control. Relative quantification of gene expression was determined using the $2^{-\Delta \Delta C T}$ method as described by Livak and Scmittgen (36). The primers used in the Qrt-PCR assay are listed as follows: sFRP4 (forward, TGGCAACGTATCTCAGCAAA; reverse, GGATGGGTGA TGAGGACTTG), GAPDH (forward, ACCACAGTCCATGC CATCACT; reverse, GTCCACCACCCTGTTGCTGTA). The specificity of Qrt-PCR products was verified by performing dissociation reaction plots.

Protein extraction and western blot analysis. Protein extraction and western blot analysis (WB) were performed as described elsewhere (37), using antibodies for anti-sFRP4 
(1:5,000, Abcam, Cambridge, UK). Rabbit anti-GAPDH (1:1,000, Sigma, St. Louis, MO, USA) was used as an internal control. Horseradish peroxisdase-conjugated secondary antibodies (1:5,000, Sigma) were used followed by enhanced chemiluminescence development (Amersham Pharmacia Biotech, Piscataway, NJ, USA). The final data were subjected to grayscale scanning and semi-quantitative analysis using Quantity One Software (Bio-Rad, Hercules, CA, USA).

TMA construction and immunohistochemistry. Formalin-fixed paraffin-embedded tissue blocks were sliced and eosinstained (H\&E) slides were prepared. Three core biopsies, 2.0-mm diameter, were selected from the paraffin-embedded tissue. The cores were transferred to tissue microarrays using the Leica Bond-III fully automated arrayer from Leica Biosystems (Aperio, CA, USA). The locations of the core samples were in random order, and the pathologist were blinded to the identity of the TMA slides. The tissue microarrays were cut into $4-\mu \mathrm{m}$ sections using a serial microtome and placed in a water bath at $50^{\circ} \mathrm{C}$, followed by its application onto positively-charged glass slides. Slides were dewaxed and then rehydrated through graded alcohols into water. After mounting, the slides were dried at room temperature for 24-48 $\mathrm{h}$ and stored at $4^{\circ} \mathrm{C}$ until further testing. To minimize loss of antigenicity, the microarray slide was processed within 1 week of cutting.

All TMA slides were evaluated in advance using an H\&E stain to assess tumor content and quality. The TMAs were placed in the Leica BOND-III instrument, which is a fully automated, random and continuous access slide-staining system that processes IHC tests simultaneously. IHC protocol F was selected in the machine, and 3 min with ER1 (epitope retrieval) was set for heat-induced epitope retrieval (HIER) parameter. Bond $^{\text {TM }}$ Ploymer Refine Detection (Leica Biosystems, DS9800) was used for detection of primary antibodies. The slides were scanned into digital pictures and expression was examined using Aperio AT2 (Leica Biosystems). Primary antibodies, anti-sFRP4 (1:5,000, Abcam) were used. The optimal titer of the primary Abs for the remainder was determined based on pre-experiment results.

Evaluation of immunohistochemical staining. Staining for sFRP4 was present in the cytoplasm and nucleus. The results were calculated using Aperio AT2 (Leica Biosystems) with digital slide viewing software. The staining intensity of sFRP4 was scored as follows: 0 , no; 1 , weak; 2 , moderate; and 3, high intensity. The distribution of positively stained cells was scored on a scale of $0-5$ as follows: 0 , no staining; $1,<20 \%$; $2,20-40 \% ; 3,40-60 \% ; 4,60-80 \%$; and 5, 80-100\%. The total score was calculated as staining intensity $\mathrm{x}$ distribution (score $\leq 6$ : weak expression; score $>6$, strong expression).

Methylation and sequencing analysis. DNA was extracted from 37 fresh-frozen non-aggressive pituitary adenomas (15-50 mg), using TRIzol reagent according to the manufacturer's protocol (Invitrogen). DNA concentration and purity were measured by UV absorbance at 260/280 nm (Nanodrop ND-1000, USA). Before carrying out the methylation analysis, we quantified the yield of extracted DNA from the samples. The extracted DNA was of sufficient quality to allow successful amplification. Bisulfite treatment of DNA was performed using The EZ-96 DNA Methylation kit (Zymo Research, Orange, CA, USA). Two overlapping PCRs were performed to amplify a 1,924 -bp area $(-820$ to $+1,104$, relative to the translation start site) of the sFRP4 promoter containing 134 CpG dinucleotides. The RNase-A enzyme (Sequenom, USA) was added to cleave the in vitro transcripts (T-cleavage assay). For every cleaved $\mathrm{CpG}$ site, the mass spectra were collected using MassARRAY Compact MALDI-TOF (Sequenom) and the spectra methylation ratios were generated by EpiTYPER software v1.0 (Sequenom).

Cell culture, DAC treatment and western blot analysis of cell lines. GH3 pituitary adenoma cell lines were cultured in Dulbecco's modified Eagle's medium (DMEM; Gibco-BRL, Gaithersburg, MD, USA) supplemented with $10 \%$ fetal bovine serum, at $37^{\circ} \mathrm{C}$ in a humidified atmosphere containing $5 \% \mathrm{CO}_{2}$. The demethylating agent, DAC (5-aza-2-deoxycytidine; Sigma), was freshly prepared in $\mathrm{ddH}_{2} \mathrm{O}$. GH3 cells $\left(3 \times 10^{5}\right.$ cells/well) in exponential growth phase were seeded in 6 -well plates. After $24 \mathrm{~h}$ of culture, cells were treated with DAC at concentration of $0,10,20,30$ and $40 \mathrm{nM}$ for $72 \mathrm{~h}$. The culture medium was replaced every $24 \mathrm{~h}$ with fresh media containing DAC. Total proteins were extracted for WB analysis, which was performed using the standard procedure, and the proteins were identified using anti-sFRP4 (1:5,000, Abcam), rabbit anti-GAPDH (1:1,000, Sigma) antibodies.

Cell viability assay (MTS). Cell viability was assessed by 3-(4,5-dimethylthiazol-2-yl)-5-(3-carboxymethoxyphenyl)2-(4-sulfophenyl)-2H-tetrazolium (MTS) assay using MTS reagent (CellTiter 96 AQueous One Solution Cell Proliferation assay, Promega). Briefly, $2 \times 10^{4}$ exponentially growing GH3 cells were seeded in 96-well culture plates with DAC at concentration of $0,10,20,40$ and $80 \mathrm{nM}$. After 24, 48, 72 of incubation at $37^{\circ} \mathrm{C}, 20 \mu \mathrm{l}$ of MTS was added to each well, and the samples incubated for a further $3 \mathrm{~h}$ at $37^{\circ} \mathrm{C}$. Plates were analyzed on a Tecan M200Pro multimode microplate reader at $492 \mathrm{~nm}$. The cell inhibition rate was calculated as follows: Inhibition rate $(\%)=(\mathrm{OD}$ of control group - OD of drug group $) /$ OD of control group x $100 \%$.

Statistical analysis. Differences between subgroups were analyzed using the Student's t-test for normally distributed continuous values, and Mann-Whitney U test for non-normally distributed continuous values. The $\chi^{2}$ test was used to analyze categorical variables. Variables that showed association with aggressiveness and recurrence of GH-secreting pituitary adenomas were subjected to univariate and multivariate analyses. Two-sided P-values of $<0.05$ were considered statistically significant. SPSS software version 17.0 (IBM Corp., Armonk, NY, USA) was used for statistical analyses.

\section{Results}

Clinical and pathological features. Details of the GH pituitary adenoma specimens included in the study are shown in Table I. Fifty-two GH-secreting pituitary adenomas met the inclusion criteria. Patient age ranged from 13 to 75 years (mean, 40.3 years; median, 39.5 years) at the time of the first 
Table I. Clinico-pathological characteristics of 52 patients with GH-secreting pituitary adenomas.

\begin{tabular}{|c|c|c|}
\hline Variables & $\mathrm{N}$ & Percentage $(\%)$ \\
\hline \multicolumn{3}{|l|}{ Gender } \\
\hline Male & 28 & 53.8 \\
\hline Female & 24 & 46.2 \\
\hline \multicolumn{3}{|l|}{ Age (years) } \\
\hline Mean & 40.3 & \\
\hline Median & 39.5 & \\
\hline \multicolumn{3}{|l|}{ Aggressiveness } \\
\hline Aggressive & 15 & 28.8 \\
\hline Non-aggressive & 37 & 71.2 \\
\hline \multicolumn{3}{|l|}{ Preoperative serum } \\
\hline \multicolumn{3}{|l|}{ GH level (ng/ml) } \\
\hline Mean & 22.82 & \\
\hline Median & 21.35 & \\
\hline \multicolumn{3}{|l|}{ Surgical extent } \\
\hline Gross total resection & 35 & 67.3 \\
\hline Residual & 17 & 32.7 \\
\hline \multicolumn{3}{|l|}{$\begin{array}{l}\text { Recurrence } \\
\text { (within } 42 \text { months) }\end{array}$} \\
\hline Yes & 11 & 21.2 \\
\hline No & 41 & 78.8 \\
\hline
\end{tabular}

$\mathrm{GH}$, growth hormone.

surgical treatment. Out of the 52 patients, 24 patients $(46.2 \%)$ were female, and $28(53.8 \%)$ were male. There were $4(26.7 \%)$ females and $11(73.3 \%)$ males in the aggressive group $(\mathrm{N}=23)$, and $20(54.1 \%)$ females and $17(45.9 \%)$ males in the non-aggressive group ( $\mathrm{N}=25)$. Gross total resection was found in $35(67.3 \%)$ out of the 52 patients. The preoperative serum $\mathrm{GH}$ results ranged from 0.13 to $48 \mathrm{ng} / \mathrm{ml}$ (mean, $22.82 \mathrm{ng} / \mathrm{ml}$, median, $21.35 \mathrm{ng} / \mathrm{ml}$ ).
Quantitative-PCR and western blot analysis. qRT-PCR revealed a significant downregulation of sFRP4 mRNA level in both aggressive- as well as non-aggressive GH-secreting pituitary adenomas, as compared to that in the normal controls $(0.031 \pm 0.006$ vs. $1.35 \pm 0.19, \mathrm{P}<0.001, \mathrm{~N}=15$ vs. $\mathrm{N}=10 ; 0.981 \pm 0.111$ vs. $1.35 \pm 0.19, \mathrm{P}<0.001, \mathrm{~N}=37$ vs. $\mathrm{N}=10$ ) (Fig. 1A). The sFRP4 mRNA level was significantly lower in aggressive group as compared to that in the non-aggressive group $(0.031 \pm 0.006$ vs. $0.981 \pm 0.111, \mathrm{P}=0.001, \mathrm{~N}=15$ vs. $\mathrm{N}=37)$ (Fig. 1A).

The sFRP4 protein expression in the three groups was assessed by WB (Fig. 1B). There was a significantly lower sFRP4 protein level in the non-aggressive group as compared to that in the normal pituitary tissues $(6.82 \pm 0.45$ vs. $14.65 \pm 1.38$, $\mathrm{P}<0.001, \mathrm{~N}=37$ vs. $\mathrm{N}=10$ ); the expression was even lower in the aggressive group as compared to that in the non-aggressive group $(4.13 \pm 0.49$ vs. $6.82 \pm 0.45, \mathrm{P}=0.004, \mathrm{~N}=15$ vs. $\mathrm{N}=37)$ (Fig. 1C).

Tissue microarrays analysis. sFRP4 expression was detected in all specimens by TMA (Fig. 2). On univariate analysis, sFRP4 expression showed no association with age, gender, and preoperative serum GH levels. However, a significant relationship was found between aggressive behavior and sFRP4 expression ( $\mathrm{P}=0.024)$ (Table II).

On comparing the total score for sFRP4 staining with the aggressive behavior, the sFRP4 expression was downregulated in most of the aggressive $\mathrm{GH}$-secreting pituitary adenomas $(10 / 15,66.7 \%)$ (Table III). Only $12(32.4 \%)$ pituitary adenomas expressed weak sFRP4 expression among the 37 non-aggressive $\mathrm{GH}$-secreting pituitary adenomas. On univariate analysis a significant association was found between sFRP4 expression and aggressiveness of tumors $(\mathrm{P}=0.024)$ (Table III). However, age, gender and preoperative serum GH level were not found to be associated with aggressiveness (Table III).

Follow-up data were available for all 52 patients. Patients were followed up for 42 months. During follow-up, 11 patients (21.2\%) experienced recurrence (Table I). Out of the 11 recurrent adenomas, $10(90.9 \%)$ had weak sFRP4 expression (Table IV). Weak sFRP4 expression was found only in 16 of 41 patients $(39 \%)$ with non-recurrent GH-secreting pituitary adenomas. On univariate analysis, weak sFRP4 expression $(\mathrm{P}=0.002)$, increased aggressiveness $(\mathrm{P}=0.034)$, and surgical

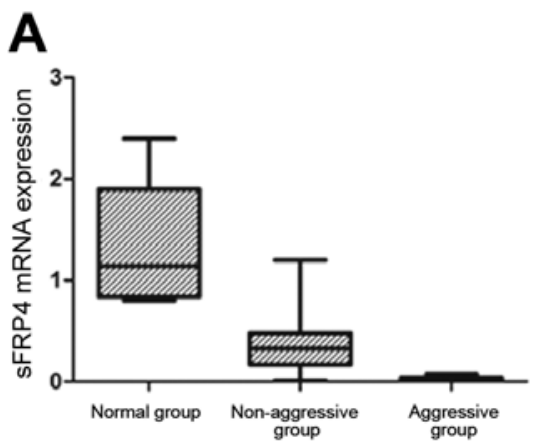

B
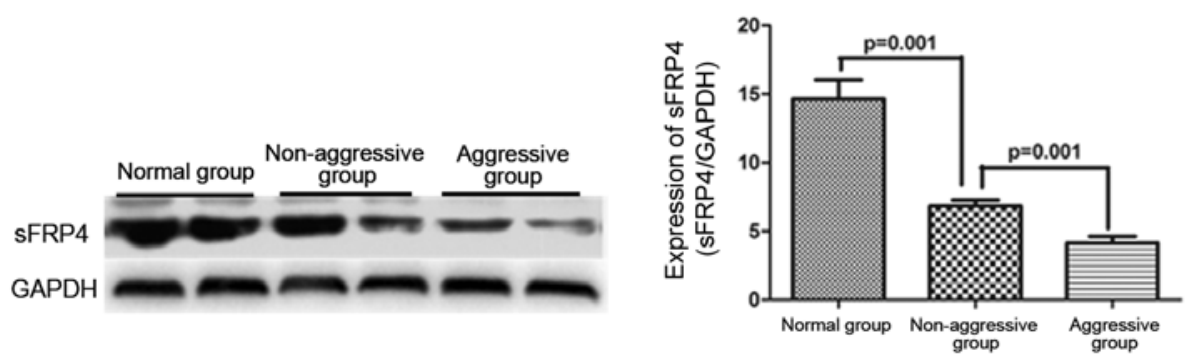

Figure 1. (A) mRNA levels of sFRP4 in normal pituitary tissues, non-aggressive and aggressive GH-secreting pituitary adenomas were assessed by qRT-PCR. (B) Protein expression of sFRP4 and GAPDH in normal pituitary tissues, non-aggressive, and aggressive pituitary adenomas were detected by western blotting. GAPDH was used as an internal control. (C) Quantitative analyses of western blot results are shown. Data are expressed as mean \pm SEM. qRT-PCR, Quantitative real-time polymerase chain reaction; GAPDH, Glyceraldehyde-3-phosphate dehydrogenase; SEM, standard error of the mean. 

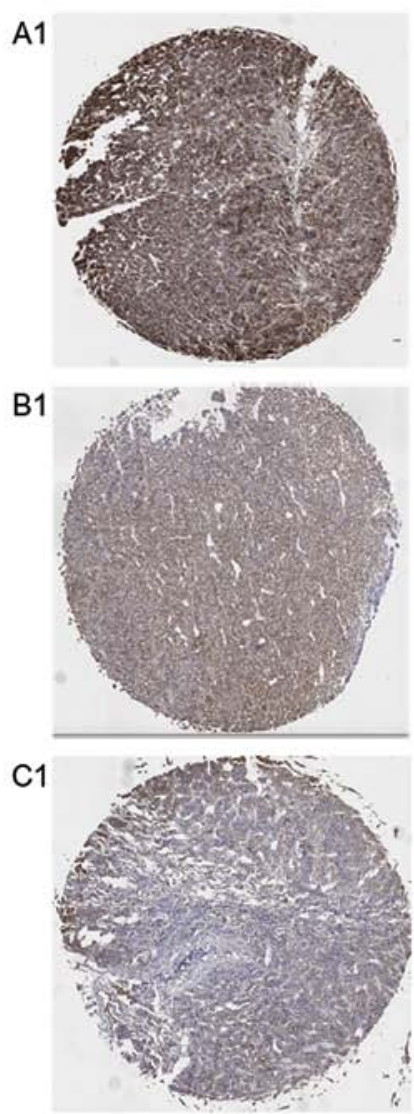

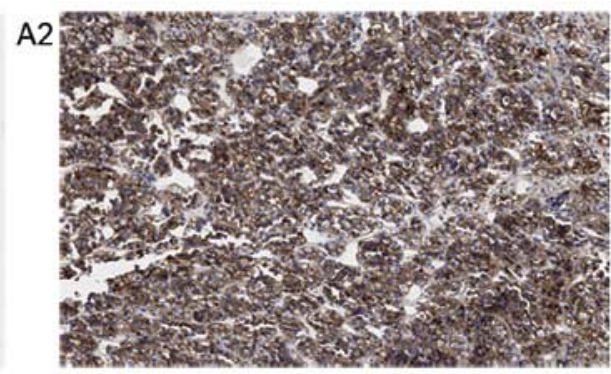

B2

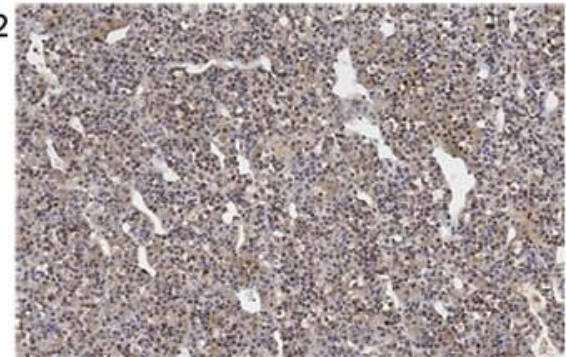

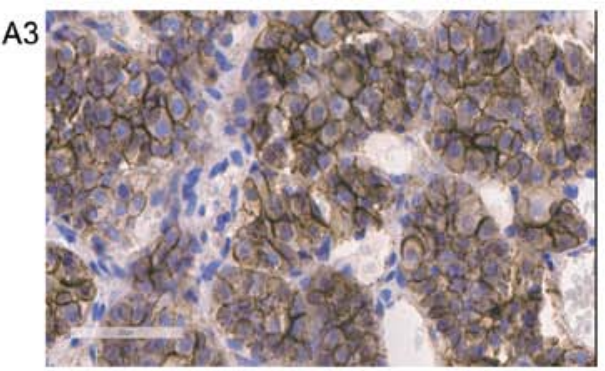
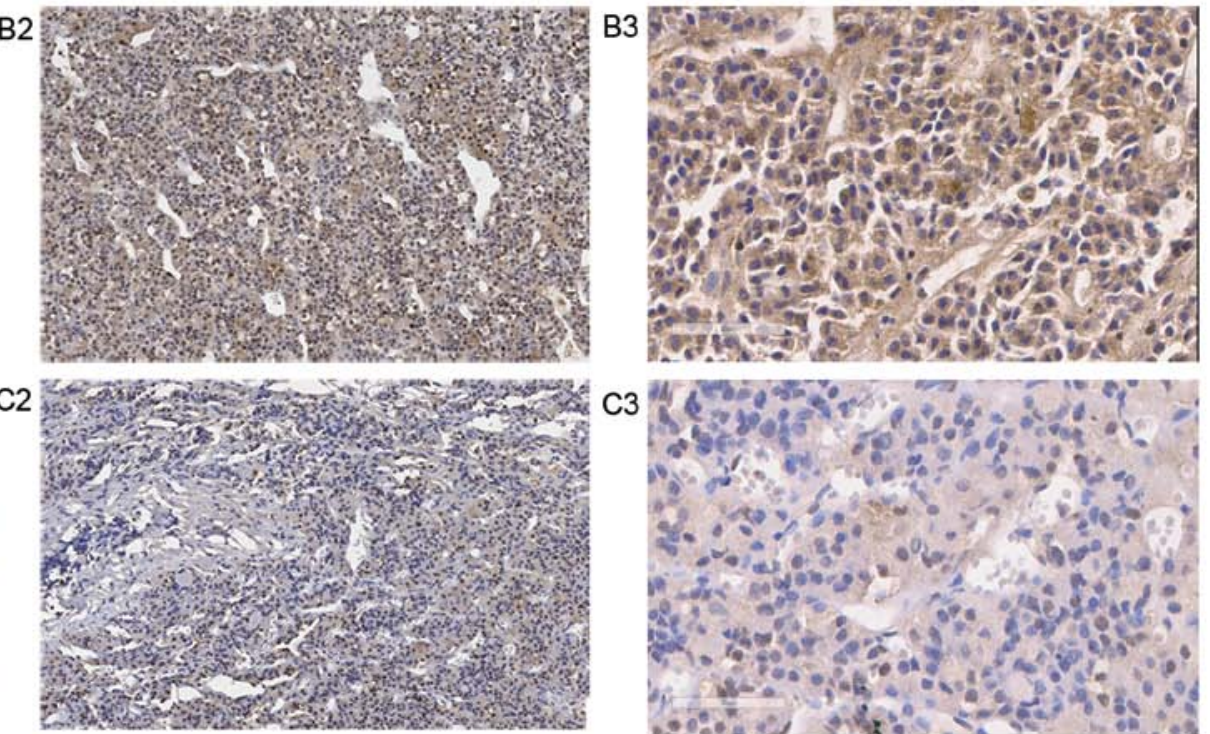

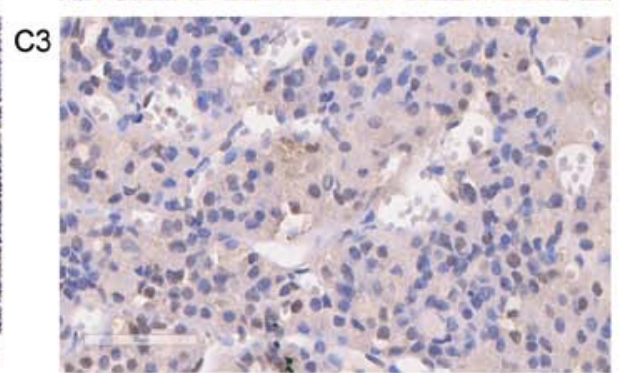

Figure 2. Expression of sFRP4 was assessed by TMA. (A) Weak sFRP4-positive cells from normal pituitary tissues (A1, x40, A2, x100 and A3, x400 magnification). (B) Weak sFRP4-positive cells from non-aggressive adenoma (B1, x40, B2, x100 and B3, x400 magnification). (C) Strong sFRP4-positive cells from aggressive pituitary adenomas $(\mathrm{C} 1, \mathrm{x} 40, \mathrm{C} 2, \mathrm{x} 100$ and $\mathrm{C} 3, \mathrm{x} 400$ magnification). TMA, tissue microarray.

Table II. Association between sFRP4 (TMA) expression and clinico-pathological characteristics.

\begin{tabular}{cccccc}
\hline \multirow{2}{*}{ Variables } & \multicolumn{2}{c}{ sFRP4 expression } & & \multicolumn{2}{c}{$\begin{array}{c}\text { Univariate } \\
\text { analysis }\end{array}$} \\
\cline { 2 - 3 } \cline { 6 - 7 } & $\begin{array}{c}\text { Weak } \\
(\mathrm{N}=22)\end{array}$ & $\begin{array}{c}\text { Strong } \\
(\mathrm{N}=30)\end{array}$ & & $\chi^{2}$ & P-value \\
& & & & &
\end{tabular}

Gender

$\begin{array}{lrrrr}\text { Male } & 14(63.6 \%) & 14(46.7 \%) & 1.471 & 0.225 \\ \text { Female } & 8(36.4 \%) & 16(53.3 \%) & & \end{array}$

Age

$\begin{array}{lrrrc}\leq 39 & 11(53.8 \%) & 15(46.2 \%) & 0 & 1 \\ >39 & 11(46.2 \%) & 15(53.8 \%) & & \\ \text { Aggressiveness } & & & & \\ \text { Yes } & 10(45.5 \%) & 5(16.7 \%) & 5.125 & 0.024 \\ \text { No } & 12(54.5 \%) & 25(83.3 \%) & & \end{array}$

Preoperative

serum

GH level

\begin{tabular}{lllll} 
High & $10(45.5 \%)$ & $13(43.3 \%)$ & 0.023 & 0.879 \\
Low & $12(54.5 \%)$ & $17(56.7 \%)$ & & \\
\hline
\end{tabular}

TMA, tissue microarray; GH, growth hormone.
Table III. Univariate and multivariate analyses for the clinicopathological correlates of aggressive GH secreting pituitary adenomas.

\begin{tabular}{|c|c|c|c|c|}
\hline \multirow[b]{2}{*}{ Variables } & \multicolumn{2}{|c|}{ Aggressiveness N (\%) } & \multicolumn{2}{|c|}{$\begin{array}{c}\text { Univariate } \\
\text { analysis }\end{array}$} \\
\hline & No $(\mathrm{N}=37)$ & Yes $(\mathrm{N}=15)$ & $\chi^{2}$ & P-value \\
\hline \multicolumn{5}{|l|}{ Gender } \\
\hline Male & $17(45.9 \%)$ & $11(73.3 \%)$ & 3.221 & 0.073 \\
\hline Female & $20(54.1 \%)$ & $4(26.7 \%)$ & & \\
\hline \multicolumn{5}{|l|}{ Age } \\
\hline$\leq 39$ & $17(45.9 \%)$ & $9(60 \%)$ & 0.843 & 0.358 \\
\hline$>39$ & $20(54.1 \%)$ & $6(40 \%)$ & & \\
\hline \multicolumn{5}{|l|}{ sFRP4 } \\
\hline Yes & $25(67.6 \%)$ & $5(33.3 \%)$ & 5.125 & 0.024 \\
\hline No & $12(32.4 \%)$ & $10(66.7 \%)$ & & \\
\hline \multicolumn{5}{|c|}{$\begin{array}{l}\text { Preoperative } \\
\text { serum }\end{array}$} \\
\hline \multicolumn{5}{|l|}{ GH level } \\
\hline Low & $23(62.2 \%)$ & $6(40 \%)$ & 2.125 & 0.145 \\
\hline High & $14(37.8 \%)$ & $9(60 \%)$ & & \\
\hline
\end{tabular}

TMA, tissue microarray; GH, growth hormone. 
Table IV. Univariate and multivariate analyses for the clinico-pathological correlates of recurrence/progression-free survival.

\begin{tabular}{|c|c|c|c|c|c|c|}
\hline \multirow[b]{2}{*}{ Variables } & \multicolumn{2}{|c|}{$\begin{array}{c}\text { Recurrence } \\
\text { (within } 42 \text { months) }\end{array}$} & \multicolumn{2}{|c|}{ Univariate analysis } & \multicolumn{2}{|c|}{ Multivariate analysis } \\
\hline & Yes $(\mathrm{N}=11)$ & No $(\mathrm{N}=41)$ & $\chi^{2}$ & $\mathrm{P}$-value & Odds ratio $(95 \% \mathrm{CI})$ & P-value \\
\hline \multicolumn{7}{|l|}{ Gender } \\
\hline Male & $6(54.5 \%)$ & $22(53.7 \%)$ & 0.003 & 0.958 & & \\
\hline Female & $5(45.5 \%)$ & $19(46.3 \%)$ & & & & \\
\hline \multicolumn{7}{|l|}{ Age } \\
\hline$\leq 39$ & $5(45.5 \%)$ & $21(51.2 \%)$ & 0.115 & 0.734 & & \\
\hline$>39$ & $6(54.5 \%)$ & $20(48.8 \%)$ & & & & \\
\hline \multicolumn{7}{|l|}{ sFRP4 (TMA) } \\
\hline Strong & $1 \quad(9.1 \%)$ & $25(61 \%)$ & 9.339 & 0.002 & $0.063(0.06-0.722)$ & 0.026 \\
\hline Weak & $10(90.9 \%)$ & $16(39 \%)$ & & & & \\
\hline \multicolumn{7}{|l|}{ Aggressiveness } \\
\hline Yes & $6(54.5 \%)$ & $9(22 \%)$ & 4.489 & 0.034 & $2.367(0.14-39.82)$ & 0.55 \\
\hline No & $5(45.5 \%)$ & $32(78 \%)$ & & & & \\
\hline \multicolumn{7}{|l|}{ Preoperative serum } \\
\hline \multicolumn{7}{|l|}{ GH level } \\
\hline Low & $5(45.5 \%)$ & $24(58.5 \%)$ & 0.602 & 0.438 & & \\
\hline High & $6(54.5 \%)$ & $17(41.5 \%)$ & & & & \\
\hline \multicolumn{7}{|l|}{ Surgical extent } \\
\hline Gross total resection & $4(36.4 \%)$ & $31(75.6 \%)$ & 6.071 & 0.014 & $0.139(0.009-2.15)$ & 0.155 \\
\hline Partial resection & $7(63.6 \%)$ & $10(24.4 \%)$ & & & & \\
\hline
\end{tabular}

A

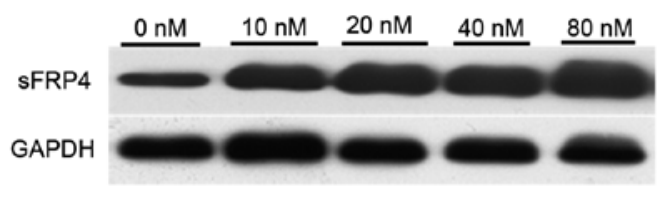

C

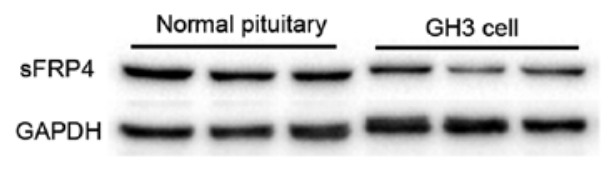

B

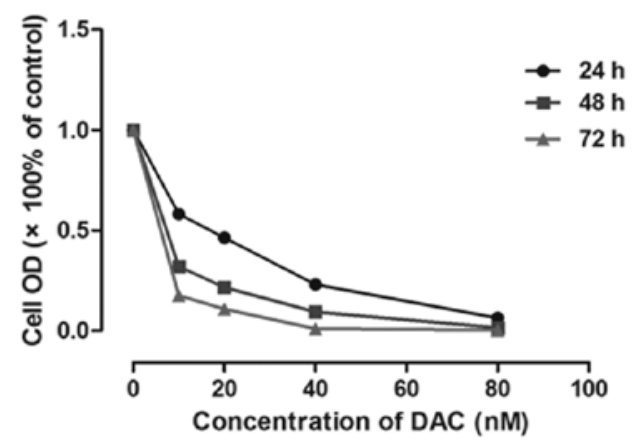

D

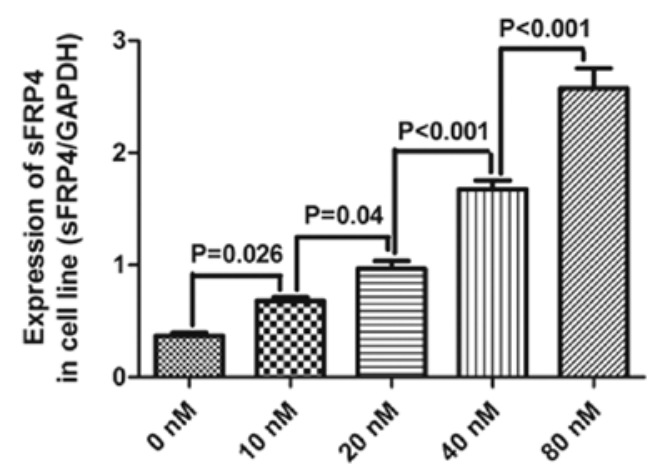

Figure 3. (A) sFRP-4 protein expression in pituitary adenoma cell lines (GH3) and normal human pituitary protein by western blot analysis. (B) Relative optical density (OD) of GH3 pituitary adenoma cells at 24, 48 and $72 \mathrm{~h}$ after DAC treatment at a range of concentrations. OD values are relative to the control (the concentration of DAC: $0 \mathrm{nM}$ ), and are determined using the MTS assay. (C) Western blots showing protein expression of sFRP4 and GAPDH in GH3 pituitary adenoma cells at $72 \mathrm{~h}$ after treatment with DAC at a concentration of $40 \mathrm{nM}$. GAPDH was used as an internal control. (D) Quantitative analyses of western blot analysis results. Data are presented as mean \pm SEM. DAC, 5-aza-2-deoxycytidine; GAPDH, glyceraldehyde-3-phosphate dehydrogenase; SEM, standard error of the mean. 
extent $(\mathrm{P}=0.014)$ were significantly associated with recurrence/ progression (Table IV). Gender, age, and preoperative serum $\mathrm{GH}$ levels were not associated with recurrence (Table IV).

On multivariate analysis, only decreased sFRP4 expression was found to be independently associated with increased aggressiveness [odds ratio (OR): 0.063, $\mathrm{P}=0.026$ ] (Table IV).

Methylation analysis of the SFRP4 promoter region. Methylation analysis was performed to investigate the contribution of hypermethylation to the loss of sFRP4 expression. The 52 samples were classified into two groups: weak sFRP4 staining and strong sFRP4 staining groups, according to the total TMA score. One CpG site $(+351 \mathrm{bp})$ was found to be hypermethylated in pituitary adenomas. The methylation ratio of the $\mathrm{CpG}$ site in the weak sFRP4 staining group was higher than that in strong SFRP4 staining group $(11.83 \pm 1.12 \mathrm{vs}$. $5.53 \pm 0.58 \%, \mathrm{P}<0.001, \mathrm{~N}=22$ vs. $\mathrm{N}=30)$.

Western blot and MTS analysis of cell lines. The sFRP4 protein expressions in pituitary adenoma cell lines (GH3), as well as in normal human pituitary tissue were assessed by western blotting. As shown in Fig. 3A, sFRP4 expression was significantly downregulated in pituitary adenoma cell lines (GH3) as compared to that in the normal human pituitary $(0.32 \pm 0.03$ vs. $0.7 \pm 0.05, \mathrm{P}=0.023, \mathrm{~N}=9$ vs. $\mathrm{N}=9$ ). MTS analysis showed a dose- and time-dependent inhibition of GH3 cell proliferation induced by DAC. A maximal inhibition of $87.6 \pm 2.2 \%$ at a concentration of $80 \mathrm{nM}$ after $72 \mathrm{~h}$ was observed. The cells were significantly inhibited at all concentrations of DAC used in this study $(0,10,20,40$ and $80 \mathrm{nM})$ after 3-day exposure. Growth curves for $\mathrm{GH} 3$ cells for various DAC concentrations are shown in (Fig. 3B), indicating that DAC suppressed cell growth in a dose-dependent and time-dependent manner. We evaluated the level of sFRP4 protein in GH3 cells after DAC treatment by WB analysis (Fig. 3C). GH3 cells after DAC treatment at the concentration of $10 \mathrm{nM}$ exhibited upregulation of sFRP4 protein compared with GH3 cells without DAC treatment $(0.32 \pm 0.03$ vs. $0.7 \pm 0.05, \mathrm{P}=0.023, \mathrm{~N}=8$ vs. $\mathrm{N}=8)$. There was a progressive increase in sFRP4 expression with the increase in DAC concentration (Fig. 3D). Both MTS and WB analysis revealed that DAC inhibits the growth of $\mathrm{GH} 3$ cells possibly by upregulating the expression of sFRP4 in $\mathrm{GH} 3$ cells.

\section{Discussion}

In this study, we compared the expression of sFRP4, both at the mRNA and protein level, in normal pituitary tissue, and in non-aggressive and aggressive GH-secreting pituitary adenomas. We documented a significant downregulation of sFRP4 mRNA levels in aggressive GH-secreting pituitary adenomas as compared to that in both normal controls and in the non-aggressive GH-secreting pituitary adenomas. This was further confirmed by WB and tissue microarray analyses. Expression of sFRP4 was negatively linked to aggressiveness and recurrence/progression of tumors, indicating that sFRP4 may be used as biomarker for predicting aggressiveness and recurrence/progression of $\mathrm{GH}$-secreting pituitary adenomas. However, no significant association of sFRP4 expression with gender, age and preoperative serum GH level, was observed.
Methylation and sequencing analysis of the sFRP4 promoter region showed it to be densely methylated in the weak sFRP4 staining group, whereas there was significantly decreased methylation in strong sFRP4 staining group. In addition, treatment with demethylation agent (5-Aza-dc) and histone deacetylase inhibitor (TSA) restored sFRP4 mRNA expression in pituitary adenoma cell lines (GH3). Our results indicate that downregulation of sFRP4 expression in the weak sFRP4 staining group correlate with $\mathrm{CpG}$ methylation of the sFRP4 promoter.

To the best of our knowledge, this study is the first to demonstrate correlation of sFRP4 expression with aggressiveness of GH-secreting pituitary adenomas. Similar results have been reported elsewhere in other cancers $(21,38)$. Even though we showed a negative relationship between weak sFRP4 expression and aggressiveness, we did not find any relationship between gender, age, preoperative serum GH level and aggressiveness of the tumors. So weak sFRP4 maybe serve as an independent factor of aggressiveness in GH-secreting pituitary adenomas.

Accumulated evidence indicates an association of low sFRP4 expression with recurrence/progression in several cancers $(39,40)$. In this study, 52 patients were followed up for a period of 42 months with clinical and imaging data, and is one of the few studies to report recurrence rates for $\mathrm{GH}$-secreting pituitary adenomas after surgery. In our study, the univariate analysis showed a significant association between low sFRP4 expression, surgical extent, tumor aggressiveness and recurrence/progression of tumors. However, on multivariate analysis, only low sFRP4 expression was an independent predictor of recurrence/progression of tumor, and tumor aggressiveness and surgical extent were not significantly associated with the recurrence/progression. This observation is in contrast to findings of some other reports that tumor resection and tumor aggressiveness were predictive factors for recurrence of pituitary adenomas $(41,42)$. The relatively short duration of follow-up may, at least partially, explain this difference.

Further, we used logistic regression analysis instead of survival analysis in consideration of potential censoring caused by low recurrence rate, so survival time was not included in our study. All of these factors could have led to the contradictory results. These differences highlight the continued need for further research with a larger sample size and longer duration of clinical follow-up.

Hypermethylation of the sFRP4 gene has been reported in various cancers, and is associated with tumor progression and malignancy $(22,43)$. In our study, silencing of SFRP4 expression correlated with the promoter methylation. At cellular level, we observed a restoration of SFRP4 expression in pituitary adenoma cells (GH3) after treatment with the demethylating agent, 5-aza-2 V-deoxycytidine. These findings are consistent with studies conducted on various other malignancies, including gastric, cervical, hepatocellular, pancreatic, oral squamous cell, breast, colon, and bladder cancers (44-49).

In conclusion, in this study weak sFRP4 expression appeared to be a predictive factor for aggressive behavior of GH-secreting pituitary adenomas. Furthermore, weak sFRP4 expression was also associated with post-operative tumor recurrence/progression. We believe that methylation of the 
sFRP4 promoter could account for the decreased sFRP4 expression.

\section{Acknowledgements}

This study was supported by the National High-tech Research and Development Program (2014AA020610), National Health and Famliy Planning Commission for Public Welfare Industry Research Project (201402008), National Natural Science Foundation of China (3157060076).

\section{References}

1. Ezzat S, Asa SL, Couldwell WT, Barr CE, Dodge WE, Vance ML and McCutcheon IE: The prevalence of pituitary adenomas: A systematic review. Cancer 101: 613-619, 2004.

2. Melmed S: Pathogenesis of pituitary tumors. Nat Rev Endocrinol 7: 257-266, 2011.

3. Horn K, Erhardt F, Fahlbusch R, Pickardt CR, Werder KV and Scriba PC: Recurrent goiter, hyperthyroidism, galactorrhea and amenorrhea due to a thyrotropin and prolactin-producing pituitary tumor. J Clin Endocrinol Metab 43: 137-143, 1976.

4. Dusek T, Kastelan D, Melada A, Baretic M, Skoric Polovina T, Perkovic Z, Giljevic Z, Jelcic J, Paladino J, Aganovic I, et al: Clinical features and therapeutic outcomes of patients with acromegaly: Single-center experience. J Endocrinol Invest 34 e382-e385, 2011

5. Hofstetter CP, Mannaa RH, Mubita L, Anand VK, Kennedy JW, Dehdashti AR and Schwartz TH: Endoscopic endonasal transsphenoidal surgery for growth hormone-secreting pituitary adenomas. Neurosurg Focus 29: E6, 2010.

6. Tabaee A, Anand VK, Barrón Y, Hiltzik DH, Brown SM, Kacker A, Mazumdar M and Schwartz TH: Endoscopic pituitary surgery: A systematic review and meta-analysis. J Neurosurg 111: 545-554, 2009.

7. Clevers $\mathrm{H}$ and Nusse $\mathrm{R}: \mathrm{Wnt} / \beta$-catenin signaling and disease. Cell 149: 1192-1205, 2012.

8. MacDonald BT, Tamai K and He X: Wnt/beta-catenin signaling: Components, mechanisms, and diseases. Dev Cell 17: 9-26, 2009.

9. Herr P, Hausmann G and Basler K: WNT secretion and signalling in human disease. Trends Mol Med 18: 483-493, 2012.

10. Gueorguiev M and Grossman AB: Pituitary gland and betacatenin signaling: From ontogeny to oncogenesis. Pituitary 12 : 245-255, 2009 .

11. Gueorguiev M and Grossman AB: Pituitary tumors in 2010: A new therapeutic era for pituitary tumors. Nat Rev Endocrinol 7: 71-73, 2011.

12. Cruciat $C M$ and Niehrs C: Secreted and transmembrane wn inhibitors and activators. Cold Spring Harb Perspect Biol 5 : a015081, 2013.

13. Constantinou T, Baumann F, Lacher MD, Saurer S, Friis R and Dharmarajan A: SFRP-4 abrogates Wnt-3a-induced beta-catenin and Akt/PKB signalling and reverses a Wnt-3a-imposed inhibition of in vitro mammary differentiation. J Mol Signal 3: 10 2008.

14. Longman D, Arfuso F, Viola HM, Hool LC and Dharmarajan AM: The role of the cysteine-rich domain and netrin-like domain of secreted frizzled-related protein 4 in angiogenesis inhibition in vitro. Oncol Res 20: 1-6, 2012.

15. Froeling FE, Feig C, Chelala C, Dobson R, Mein CE, Tuveson DA Clevers H, Hart IR and Kocher HM: Retinoic acid-induced pancreatic stellate cell quiescence reduces paracrine Wnt-betacatenin signaling to slow tumor progression. Gastroenterology 141: 1486-1497, 2011.

16. Granados-Principal S, Quiles JL, Ramirez-Tortosa C, Camacho-Corencia P, Sanchez-Rovira P, Vera-Ramirez L and Ramirez-Tortosa MC: Hydroxytyrosol inhibits growth and cell proliferation and promotes high expression of sfrp4 in rat mammary tumours. Mol Nutr Food Res 55 (Suppl 1): S117-S126, 2011.

17. Frank B, Hoffmeister M, Klopp N, Illig T, Chang-Claude J and Brenner H: Single nucleotide polymorphisms in Wnt signaling and cell death pathway genes and susceptibility to colorectal cancer. Carcinogenesis 31: 1381-1386, 2010.
18. Hrzenjak A, Tippl M, Kremser ML, Strohmeier B, Guelly C, Neumeister D, Lax S, Moinfar F, Tabrizi AD, Isadi-Moud N, et al: Inverse correlation of secreted frizzled-related protein 4 and beta-catenin expression in endometrial stromal sarcomas. J Pathol 204: 19-27, 2004.

19. O'Hurley G, Perry AS, O'Grady A, Loftus B, Smyth P, O'Leary JJ, Sheils O, Fitzpatrick JM, Hewitt SM, Lawler M, et al: The role of secreted frizzled-related protein 2 expression in prostate cancer. Histopathology 59: 1240-1248, 2011.

20. Saran U, Arfuso F, Zeps N and Dharmarajan A: Secreted frizzled-related protein 4 expression is positively associated with responsiveness to cisplatin of ovarian cancer cell lines in vitro and with lower tumour grade in mucinous ovarian cancers. BMC Cell Biol 13: 25, 2012.

21. Marsit CJ, Karagas MR, Andrew A, Liu M, Danaee H, Schned AR, Nelson HH and Kelsey KT: Epigenetic inactivation of SFRP genes and TP53 alteration act jointly as markers of invasive bladder cancer. Cancer Res 65: 7081-7085, 2005.

22. Qi J, Zhu YQ, Luo J and Tao WH: Hypermethylation and expression regulation of secreted frizzled-related protein genes in colorectal tumor. World J Gastroenterol 12: 7113-7117, 2006.

23. Chung MT, Lai HC, Sytwu HK, Yan MD, Shih YL, Chang CC Yu MH, Liu HS, Chu DW and Lin YW: SFRP1 and SFRP2 suppress the transformation and invasion abilities of cervical cancer cells through Wnt signal pathway. Gynecol Oncol 112: 646-653, 2009

24. Elston MS, Gill AJ, Conaglen JV, Clarkson A, Shaw JM, Law AJ, Cook RJ, Little NS, Clifton-Bligh RJ, Robinson BG, et al: Wnt pathway inhibitors are strongly down-regulated in pituitary tumors. Endocrinology 149: 1235-1242, 2008.

25. Hong L, Wu Y, Feng J, Yu S, Li C, Wu Y, Li Z, Cao L, Wang F and Zhang Y: Overexpression of the cell adhesion molecule claudin-9 is associated with invasion in pituitary oncocytomas. Hum Pathol 45: 2423-2429, 2014.

26. Wu Y, Bai J, Li Z, Wang F, Cao L, Liu C, Yu S, Yu G and Zhang Y: Low expression of secreted frizzled-related protein 4 in aggressive pituitary adenoma. Pituitary 18: 335-342, 2015.

27. Choi JD and Lee JS: Interplay between epigenetics and genetics in Cancer. Genomics Inform 11: 164-173, 2013.

28. Kinoshita T, Nomoto S, Kodera Y, Koike M, Fujiwara M and Nakao A: Decreased expression and aberrant hypermethylation of the SFRP genes in human gastric cancer. Hepatogastroenterology 58: 1051-1056, 2011

29. Urakami S, Shiina H, Enokida H, Kawakami T, Kawamoto K, Hirata H, Tanaka Y, Kikuno N, Nakagawa M, Igawa M, et al: Combination analysis of hypermethylated Wnt-antagonist family genes as a novel epigenetic biomarker panel for bladder cancer detection. Clin Cancer Res 12: 2109-2116, 2006.

30. Liu TH, Raval A, Chen SS, Matkovic JJ, Byrd JC and Plass C: $\mathrm{CpG}$ island methylation and expression of the secreted frizzledrelated protein gene family in chronic lymphocytic leukemia. Cancer Res 66: 653-658, 2006.

31. Perry AS, O'Hurley G, Raheem OA, Brennan K, Wong S, O'Grady A, Kennedy AM, Marignol L, Murphy TM, Sullivan L, et al: Gene expression and epigenetic discovery screen reveal methylation of SFRP2 in prostate cancer. Int J Cancer 132: 1771-1780, 2013.

32. Kawakami K, Yamamura S, Hirata H, Ueno K, Saini S, Majid S, Tanaka Y, Kawamoto K, Enokida H, Nakagawa M, et al: Secreted frizzled-related protein-5 is epigenetically downregulated and functions as a tumor suppressor in kidney cancer. Int J Cancer 128: 541-550, 2011.

33. Zhang YW, Miao YF, Yi J, Geng J, Wang R and Chen LB: Transcriptional inactivation of secreted frizzled-related protein 1 by promoter hypermethylation as a potential biomarker for non-small cell lung cancer. Neoplasma 57: 228-233, 2010.

34. Su HY, Lai HC, Lin YW, Liu CY, Chen CK, Chou YC, Lin SP, Lin WC, Lee HY and Yu MH: Epigenetic silencing of SFRP5 is related to malignant phenotype and chemoresistance of ovarian cancer through Wnt signaling pathway. Int J Cancer 127: 555-567, 2010.

35. Suzuki H, Watkins DN, Jair KW, Schuebel KE, Markowitz SD, Chen WD, Pretlow TP, Yang B, Akiyama Y, Van Engeland M, et al: Epigenetic inactivation of SFRP genes allows constitutive WNT signaling in colorectal cancer. Nat Genet 36: 417-422, 2004.

36. Livak KJ and Schmittgen TD: Analysis of relative gene expression data using real-time quantitative PCR and the 2(-Delta Delta C(T)) method. Methods 25: 402-408, 2001. 
37. Zhao $\mathrm{P}$, Wang $\mathrm{H}$, Gao $\mathrm{H}$, Li $\mathrm{C}$ and Zhang $\mathrm{Y}$ : Reversal of multidrug resistance by magnetic chitosan- $\mathrm{Fe}_{3} \mathrm{O}_{4}$ nanoparticleencapsulated $\mathrm{MDR}_{1}$ siRNA in glioblastoma cell line. Neurol Res 35: 821-828, 2013.

38. Horvath LG, Lelliott JE, Kench JG, Lee CS, Williams ED, Saunders DN, Grygiel JJ, Sutherland RL and Henshall SM: Secreted frizzled-related protein 4 inhibits proliferation and metastatic potential in prostate cancer. Prostate 67: 1081-1090, 2007.

39. Páez D, Gerger A, Zhang W, Yang D, Labonte MJ, Benhanim L, Kahn M, Lenz F, Lenz C, Ning Y, et al: Association of common gene variants in the $\mathrm{WNT} / \beta$-catenin pathway with colon cancer recurrence. Pharmacogenomics J 14: 142-150, 2014.

40. Yip PY, Kench JG, Rasiah KK, Benito RP, Lee CS, Stricker PD, Henshall SM, Sutherland RL and Horvath LG: Low AZGP1 expression predicts for recurrence in margin-positive, localized prostate cancer. Prostate 71: 1638-1645, 2011.

41. Shimon I, Cohen ZR, Ram Z and Hadani M: Transsphenoidal surgery for acromegaly: endocrinological follow-up of 98 patients. Neurosurgery 48: 1239-1243; discussion 1244-1235, 2001.

42. Shirvani M and Motiei-Langroudi R: Transsphenoidal surgery for growth hormone-secreting pituitary adenomas in 130 patients. World Neurosurg 81: 125-130, 2014.

43. Nojima M, Suzuki H, Toyota M, Watanabe Y, Maruyama R, Sasaki S, Sasaki Y, Mita H, Nishikawa N, Yamaguchi K, et al: Frequent epigenetic inactivation of SFRP genes and constitutive activation of Wnt signaling in gastric cancer. Oncogene 26: 4699-4713, 2007.
44. Lin YW, Chung MT, Lai HC, De Yan M, Shih YL, Chang CC and Yu MH: Methylation analysis of SFRP genes family in cervical adenocarcinoma. J Cancer Res Clin Oncol 135: 1665$1674,2009$.

45. Shih YL, Hsieh CB, Yan MD, Tsao CM, Hsieh TY, Liu CH and Lin YW: Frequent concomitant epigenetic silencing of SOX1 and secreted frizzled-related proteins (SFRPs) in human hepatocellular carcinoma. J Gastroenterol Hepatol 28: 551-559, 2013.

46. Botla SK, Gholami AM, Malekpour M, Moskalev EA, Fallah M, Jandaghi P, Aghajani A, Bondar IS, Omranipour R, Malekpour F, et al: Diagnostic values of GHSR DNA methylation pattern in breast cancer. Breast Cancer Res Treat 135: 705-713, 2012.

47. Bu XM, Zhao CH, Zhang N, Gao F, Lin S and Dai XW: Hypermethylation and aberrant expression of secreted frizzledrelated protein genes in pancreatic cancer. World J Gastroenterol 14: 3421-3424, 2008.

48. Kohno H, Amatya VJ, Takeshima Y, Kushitani K, Hattori N, Kohno N and Inai K: Aberrant promoter methylation of WIF-1 and SFRP1, 2, 4 genes in mesothelioma. Oncol Rep 24: 423-431, 2010.

49. Griffiths EA, Gore SD, Hooker C, McDevitt MA, Karp JE, Smith BD, Mohammad HP, Ye Y, Herman JG and Carraway HE: Acute myeloid leukemia is characterized by Wnt pathway inhibitor promoter hypermethylation. Leuk Lymphoma 51: $1711-1719,2010$ 